\title{
Attitudes of South Tyrolean University Students towards German Varieties
}

\author{
Mara Maya Victoria Leonardi
}

Faculty of Education, Free University of Bozen-Bolzano, 39100 Bolzano, Italy; mara.leonardi@unibz.it

Citation: Leonardi, Mara Maya Victoria. 2021. Attitudes of South Tyrolean University Students towards German Varieties. Languages 6: 137. https://doi.org/10.3390/ languages6030137

Academic Editor: Marco Tamburelli

Received: 8 May 2021

Accepted: 3 August 2021

Published: 13 August 2021

Publisher's Note: MDPI stays neutral with regard to jurisdictional claims in published maps and institutional affiliations.

Copyright: (C) 2021 by the author. Licensee MDPI, Basel, Switzerland. This article is an open access article distributed under the terms and conditions of the Creative Commons Attribution (CC BY) license (https:// creativecommons.org/licenses/by/ $4.0 /)$.

\begin{abstract}
This paper examines language attitudes of South Tyroleans towards German varieties used in educational institutions by means of a questionnaire survey with 55 university students. The aim of this paper is to provide an insight into subjects' attitudes towards their own and other German (standard) varieties, with a focus on the sociolinguistic situation in South Tyrol (northern Italy). Previous studies have shown that the German-speaking community often have the notion that their own standard variety is deficient combined with a feeling of linguistic inferiority towards German speakers from Germany. Therefore, this article seeks to answer the following research questions: Which attitudes do South Tyrolean university students have towards the different German (standard) varieties? Do university teacher-training students get in touch with the concept of the pluricentric variation within the German standard variety during their education? Results reveal that despite a certain awareness of the issue of linguistic variation in the German language, the standard variety used in Germany still enjoys high prestige among our subjects compared to other German standard varieties. Moreover, results show that the students were hardly confronted with the subject of the German standard variety used in South Tyrol or with the variation of the German language during their high school years. However, this changes as soon as they attend university.
\end{abstract}

Keywords: sociolinguistics; language attitudes; pluricentricity; linguistic variation; German; South Tyrol; educational institution

\section{Introduction}

Despite the enormous work which has been done in fields like social psychology, anthropology, sociolinguistics, or language learning research, defining the concept of 'attitude' is by no means straightforward. Although numerous researchers and investigators have provided a wide range of definitions (e.g., Gardner and Lambert 1972; Fishbein and Ajzen 1975; Baker 1992), "there is little agreement about what an attitude is, how it is formed or changed, and what role, if any, it plays in influencing or determining behavior" (Fishbein and Ajzen 1975, p. v). Ajzen (2005, p. 3) suggests that attitude is "a disposition to respond favorably or unfavorably to an object, person, institution, or event", which "cannot be objectively and directly observed and measured" as stated by Lasagabaster (2005, p. 399).

The main object of this paper is to examine speakers' attitudes towards the different German varieties used in South Tyrol, a multilingual province in northern Italy, where Italian, German, and Ladin are recognized as official languages. Earlier language attitude work in South Tyrol demonstrated ambiguous outcomes (Section 2.1). On the one hand, previous empirical studies have shown that attitudes towards the Southern Bavarian variety $^{1}$ are almost exclusively positive, while attitudes towards the German standard variety sometimes tend to be negative: the German standard variety is often associated with educational institutions, with German tourists from Germany, and it is sometimes even perceived as a foreign language (e.g., Abel 2007; Leonardi 2020). Moreover, the German-speaking community often shows a linguistic inferiority complex towards German speakers from Germany. On the other hand, the standard variety from Germany serves as 
a prestigious variety (e.g., Riehl 1994; Ciccolone 2010; Hofer 2020; Leonardi, forthcoming). Similar results have been found in Austria and Switzerland too. Austrians and Swiss people often evaluate and consider the standard variety from Germany as more correct and prestigious than their own standard variety (e.g., Ammon 1995; Scharloth 2005a, 2005b; Schmidlin 2011; Gatta 2017; de Cillia and Ransmayr 2019).

The second aim of this paper examines the concept of pluricentricity among South Tyrolean university students. Clyne (1992a, p. 1) defines a pluricentric language as one "with several interacting centres, each providing a national variety with at least some of its own (codified) norms". German, among other languages, is considered a pluricentric language (Ammon 1995, 2015; Clyne 1992b, 2004). The German standard variety has three 'full centres' (so-called Vollzentren), Germany, Austria, Switzerland, and four 'semicentres' (so-called Halbzentren), Liechtenstein, Luxembourg, East Belgium and South Tyrolcountries or regions in which German has the status of an official language. The latter, the so-called Halbzentren, lack of their own linguistic codex, i.e., comprehensive dictionaries, grammars, or pronunciation guides (Ammon 1995) (Section 2.2). For further discussion on the concept of pluricentricity and some case studies on pluricentric languages, cf. Clyne (2004), Soares da Silva (2014) and Dollinger (2019). Although the current study focuses on German varieties in South Tyrol, parallels can be drawn with speakers of other pluricentric languages. Moreover, the current paper provides recommendations for the educational and pedagogical context and, more importantly, aims at creating awareness among speakers of pluricentric languages as well as on second/foreign language learners learning a (pluricentric) language.

On the basis of a questionnaire survey, which was conducted in spring 2019 among 55 teacher-training students attending university in South Tyrol, the aim of this paper is to provide an insight into subjects' language attitudes towards their own and other German (standard) varieties. There were two main reasons for conducting this empirical study within the educational context. Firstly, there is a clear-cut distinction between private/informal and official/formal domains, i.e., informal domains (e.g., family, friends) are reserved for the Southern Bavarian variety, while more formal domains (e.g., education, politics, media) favour the use of the standard variety (Section 2). Secondly, the context of the educational domain can have a significant impact on language attitudes, learners' opinions and their language learning success (e.g., Mioni 1990; Baker 1992; Lasagabaster 2005; ASTAT 2015; de Cillia and Ransmayr 2019). This underlines not only the important role of a (language) teacher, but also the experiences $\mathrm{s} /$ he encounters during his/her educational path.

The article is structured as follows: Section 2 briefly summarizes the research on the sociolinguistic situation in South Tyrol, followed by Section 3, in which the methodological approaches are outlined. Results will be presented in Section 4 and discussed in Section 5. Finally, this paper will be concluded by highlighting the importance of discussing linguistic variation of the German language in university education.

\section{Sociolinguistic Situation in South Tyrol}

South Tyrol is a multilingual province in the north of Italy, bordering Austria and Switzerland. Although it is part of Italy, the vast majority of the South Tyrolean population (69.64\%) belongs to the German-speaking language group, followed by the Italian- $(25.84 \%)$ and Ladin-speaking group (4.52\%) (ASTAT 2020, p. 15). Most members of the Germanspeaking community use a non-standard variety, i.e., a Tyrolean dialect, which belongs to the Southern Bavarian dialect group, from now on Southern Bavarian variety, in their everyday spoken communication, such as with family members and friends, and at workplace settings, while the German standard variety is rarely spoken outside of the school setting $^{2}$ (Saxalber-Tetter 1982; Lanthaler 1990; Riehl 2000, 2007; ASTAT 2015). Although the German standard variety is rarely spoken in everyday life, it serves as a prestigious variety (Riehl 1994; Ciccolone 2010; Hofer 2020), as discussed in Section 2.1. 


\subsection{Language Attitudes in South Tyrol}

Earlier language attitude work conducted in South Tyrol demonstrated ambiguous findings. On the one hand, research has demonstrated that the Southern Bavarian variety plays a crucial and important role among its speakers' identity, it is perceived as their own language, as more emotional, while the German standard variety is sometimes perceived as foreign language or even labelled as Distanzsprache (e.g., Riehl 2001, p. 23; Abel 2007; Glück et al. 2019; Leonardi 2020, forthcoming). On the other hand, the Southern Bavarian variety-as a non-standard variety - has no official status and therefore is often considered as inferior, while the German standard variety—as an official language-enjoys status and prestige both within and outside South Tyrol. Moreover, South Tyroleans claim that it is important and necessary to have an adequate language competence in the standard variety, as the usage of the Southern Bavarian variety is restricted to South Tyrol only (Abel 2007; Leonardi 2020, forthcoming).

Since the educational context can have a significant impact on pupils' language attitudes and their language learning success, Hofer $(2017,2020)$ and Leonardi and Hofer (2020) recently examined the correction patterns ${ }^{3}$ among South Tyrolean in-service teachers and teacher-training students. Their empirical studies revealed that both current and future teachers tend to adopt the norms of the standard variety from Germany by avoiding their own norms. They found out that regionally marked, correct standard variants (e.g., primary South Tyrolisms ${ }^{4}$ ), which are no actual 'mistakes', were marked as stylistically inadequate or even as incorrect when correcting a fictitious student essay, while foreign national varieties (e.g., Austriacisms or Deutschlandisms), which are less common in South Tyrol, were marked less often. The resulting consequence of such correction patterns is that expressions or particular linguistic features which belong to their own standard variety are deliberately avoided or even lowered in status as they are not considered 'standard' (see Section 4). The codification of such particularities, however, is a crucial criterion for their status, as presented in Section 2.2 (see also Muhr 2005).

\subsection{German in South Tyrol}

As one of the four semi-centres (Halbzentren, Ammon 1995, p. 96; Ammon et al. 2016, p. XII) of Standard German, South Tyrol does not (yet) have its own officially recognized language codex, such as dictionaries, grammars, or pronunciation guides-even though the German standard variety used in South Tyrol possesses a number of linguistic features that distinguish it from other German standard varieties. Some of these features ${ }^{5}$, especially at the lexical level, have been described in the dictionary Variantenwörterbuch des Deutschen (Ammon et al. 2004, 2016), in Abfalterer (2007), as well as in corpora such as the Korpus Südtirol (Abel and Anstein 2011; Anstein et al. 2011). Although official publications on phonetics or grammatical aspects of the German standard variety used in South Tyrol do not (yet) exist, the Variantenwörterbuch des Deutschen makes an important contribution towards its codification as it provides a comprehensive view of the lexical differences between the German standard variety used in Austria, Germany, Switzerland, East Belgium, Liechtenstein, Luxembourg and South Tyrol. Recent investigations revealed, however, that in cases of linguistic insecurities the Online-Duden and the Duden are usually used as reference work while the Variantenwörterbuch des Deutschen is rarely consulted by both teachers (Hofer 2017, p. 90) and university students (Leonardi and Hofer 2020, pp. 157-58).

Although it is known that German is a pluricentric language with several varieties, it has been shown in the literature that there is often ignorance of one's own variety as well as little knowledge and unawareness regarding the standard variation within the German language (e.g., Ammon 1995, 2015; Clyne 1992b, 2004). This lack of knowledge about standard variation within the German language can lead to the tendency that school teachers mark as incorrect one's own as well as other national variants, because teachers-in their task as proof-readers-judge what is correct and what is not. Even though educational institutions and language-norm authorities (i.e., teachers and teachertraining students) play an important role in communicating language norms, it has been 
shown that pluricentric variation is rarely discussed in school teaching or teacher-training education (e.g., Ammon 1995; Muhr 1995; Fink 2014, 2016; de Cillia and Ransmayr 2019; Hofer 2020). Precisely for this reason, but also in order to communicate a confident use of the German standard variety and given the central role of teachers in teaching language norms and providing positive language attitudes, linguistic variation of the German language has to be made a subject of discussion at school, at teacher training courses and in teaching materials, as argued by Saxalber-Tetter and Lanthaler (1994), Fink (2016), and more recently also by de Cillia and Ransmayr (2019), Hofer (2020) and Leonardi and Hofer (2020).

\section{Materials and Methods}

Data collection took place during a regular lecture at a teacher training course at the university in Brixen/Bressanone in March $2019^{6}$ in South Tyrol. Since the foundation of the Free University of Bozen-Bolzano in 1997, training for preschools and primary schools has taken place exclusively at the Faculty of Education in Brixen/Bressanone ${ }^{7}$. Subjects were only told that the questionnaire survey was about German in South Tyrolean schools. The questionnaire consisted of three parts (see Appendix A for the English translation and Appendix B for the original German version):

(1) Questions concerning the German language, dictionary usage and linguistic variation;

(2) A fictitious student essay;

(3) Personal information, such as gender, age, place of residence, and language usage in everyday life.

The focus of the current paper lies on the questions of part (1), while the analysis of university students' correction patterns ${ }^{8}$ can be found in Leonardi and Hofer (2020). The essay and a shorter, slightly changed version of the questionnaire were adopted from Hofer (2020, p. 243).

The following four questions ${ }^{9}$ from the questionnaire (part (1)) will be analysed in the current paper:

1. In your opinion, does a 'particularly good German' exist? If so, where (country, region) is it spoken?

2. Do you think there are Standard German words which are exclusively used in South Tyrol but not in any other German-speaking areas? If so, can you give examples? Do you consider them to be equally correct as or less correct than their equivalents used in other German-speaking countries?

3. Was or is linguistic variation a topic of discussion during your education?

4. In your opinion, how important is the discussion of the variation within the German language at school?

\subsection{Participants}

All subjects attended their first year of the Master in Primary Education at the Faculty of Education in Brixen/Bressanone.

\subsubsection{Gender and Age}

In total, 55 university students-53 females and 2 males-with an age range of 19 to 30 years (mean age $=20.9$ years) participated in the survey.

\subsubsection{Native Language(s)}

A total of 50 out of 55 students declare a Southern Bavarian variety as their native language (L1); one student, who has been living in South Tyrol for nine to ten years, declares to have Moroccan as L1; and four subjects name two varieties as their L1. Three out of these four students claim the Southern Bavarian variety and Italian as their L1, and one student claims the Southern Bavarian variety and Standard German as his/her L1. 


\subsubsection{Varieties Used in Everyday Life}

Even though the Southern Bavarian variety is the most frequently used code between subjects' and their mothers $(n=50 / 55)$, fathers $(n=46 / 54)$, siblings $(n=48 / 53)$, partners $(n=49 / 53)$, children $(n=10 / 11)$ and friends $(n=44 / 55)$, Table 1 demonstrates the linguistic diversity and complexity in everyday communication. Some students claim to use exclusively Standard Italian in interaction with their mother $(n=1 / 55)$, father $(n=5 / 54)$, siblings $(n=1 / 53)$ or partner $(n=1 / 53)$, and some students state the use of both the Southern Bavarian variety and Standard Italian in interaction with their mother $(n=3 / 55)$, siblings $(n=2 / 53)$, partner $(n=1 / 53)$ or friends $(n=6 / 55)$. All the other language combinations presented in Table 1 are mentioned one or two times only. The numbers of Tables 1 and 2 are based on the questionnaires ${ }^{10}$ provided by the subjects themselves.

Table 1. Language use in informal situations (based on the questionnaire).

\begin{tabular}{|c|c|c|c|c|c|c|}
\hline & Mother & Father & Sibling/s & Partner & Children & Friends \\
\hline Southern Bavarian variety & $n=50$ & $n=46$ & $n=48$ & $n=49$ & $n=10$ & $n=44$ \\
\hline Southern Bavarian variety and Standard Italian & $n=3$ & $n=0$ & $n=2$ & $n=1$ & $n=0$ & $n=6$ \\
\hline Southern Bavarian variety, Standard Italian and Italian variety & $n=0$ & $n=1$ & $n=0$ & $n=0$ & $n=0$ & $n=2$ \\
\hline Standard Italian & $n=1$ & $n=5$ & $n=1$ & $n=1$ & $n=0$ & $n=0$ \\
\hline other variety & $n=1$ & $n=1$ & $n=0$ & $n=0$ & $n=0$ & $n=0$ \\
\hline Standard German & $n=0$ & $n=1$ & $n=0$ & $n=0$ & $n=0$ & $n=0$ \\
\hline Southern Bavarian variety and Standard German & $n=0$ & $n=0$ & $n=0$ & $n=0$ & $n=1$ & $n=0$ \\
\hline Southern Bavarian variety and Italian variety & $n=0$ & $n=0$ & $n=1$ & $n=0$ & $n=0$ & $n=0$ \\
\hline Southern Bavarian variety and umgangssprachliches Deutsch & $n=0$ & $n=0$ & $n=0$ & $n=0$ & $n=0$ & $n=1$ \\
\hline Southern Bavarian variety, Standard Italian and other variety & $n=0$ & $n=0$ & $n=0$ & $n=0$ & $n=0$ & $n=1$ \\
\hline Southern Bavarian variety, Italian variety and other variety & $n=0$ & $n=0$ & $n=0$ & $n=0$ & $n=0$ & $n=1$ \\
\hline Southern Bavarian variety and other variety & $n=0$ & $n=0$ & $n=1$ & $n=0$ & $n=0$ & $n=0$ \\
\hline Standard Italian and Italian variety & $n=0$ & $n=0$ & $n=0$ & $n=1$ & $n=0$ & $n=0$ \\
\hline Standard Italian and other variety & $n=0$ & $n=0$ & $n=0$ & $n=1$ & $n=0$ & $n=0$ \\
\hline $\mathrm{n} / \mathrm{a}$ & $n=0$ & $n=1$ & $n=2$ & $n=2$ & $n=44$ & $n=0$ \\
\hline Total & $\mathrm{N}=55$ & $\mathrm{~N}=55$ & $\mathrm{~N}=55$ & $\mathrm{~N}=55$ & $\mathrm{~N}=55$ & $\mathrm{~N}=55$ \\
\hline
\end{tabular}

Table 2. Language use in formal situations (based on the questionnaire).

\begin{tabular}{|c|c|c|}
\hline & University Professors & Children at Preschool/Primary School \\
\hline Standard German & $n=47$ & $n=30$ \\
\hline Standard German and Southern Bavarian variety & $n=2$ & $n=11$ \\
\hline $\begin{array}{c}\text { Standard German, umgangssprachliches Deutsch and Southern } \\
\text { Bavarian variety }\end{array}$ & $n=0$ & $n=3$ \\
\hline Standard German and umgangssprachliches Deutsch & $n=5$ & $n=2$ \\
\hline Umgangssprachliches Deutsch & $n=1$ & $n=2$ \\
\hline Standard German, umgangssprachliches Deutsch, Standard Italian & $n=0$ & $n=2$ \\
\hline Standard German, Standard Italian and Southern Bavarian variety & $n=0$ & $n=2$ \\
\hline Umgangssprachliches Deutsch and Southern Bavarian variety & $n=0$ & $n=1$ \\
\hline $\begin{array}{c}\text { Standard German, Standard Italian, Southern Bavarian variety and } \\
\text { other variety }\end{array}$ & $n=0$ & $n=1$ \\
\hline $\begin{array}{c}\text { Standard German, umgangssprachliches Deutsch, Standard Italian and } \\
\text { other variety }\end{array}$ & $n=0$ & $n=1$ \\
\hline Total & $\mathrm{N}=55$ & $\mathrm{~N}=55$ \\
\hline
\end{tabular}

This linguistic complexity can also be observed within more formal situations, however, to a lesser degree. As can be seen in Table 2, in a more formal context the majority of our subjects claim to use Standard German $(n=47 / 55)$ in interaction with university professors, while 5 students use both Standard German and umgangssprachliches Deutsch ${ }^{11}$ (colloquial German). In interactions with children at preschool or primary school, 30 students state to use Standard German only, while 11 students claim to use both Standard German and the Southern Bavarian variety. All the other language combinations presented in Table 2 are mentioned three times or less.

Internal multilingualism, which refers to the control and/or usage of related varieties (Wandruszka 1979), represents an important aspect of the South Tyrolean reality: the 
Southern Bavarian variety is the most used code in subjects' everyday life in interaction with family members, partners, their own children and friends (Table 1), while the German standard variety is mainly used within the educational setting (Table 2). This clear-cut distinction between formal and informal domains has already been observed in previous empirical studies, as for instance in Saxalber-Tetter (1982), Lanthaler (1990), Riehl (2000), ASTAT (2015), or more recently also in Leonardi (2020).

External multilingualism, which refers to the knowledge of unrelated varieties, is similarly important within the South Tyrolean context. As shown in Table 1, Italian varieties are also commonly used with family members, partners or friends (however, not with children). Besides German and Italian varieties, English, Moroccan and Albanian are also mentioned by our subjects, revealing a multilingual environment of our university students.

\section{Results}

Regarding question (1), asking our subjects whether they think that a 'particularly good German' exists at all, the majority $(n=38 ; 69.1 \%)$ disagrees, while $17(30.9 \%)$ students are convinced that a 'particularly good German' as such exists and it is either spoken in Germany $(n=4)$, in northern Germany $(n=9)$, central Germany $(n=2)$ or certain parts of Germany $(n=1)$ (one answer was missing). A one-sample proportion test showed that the answers of the two groups differed significantly $\left(\mathrm{x}^{2}=7.3 ; \mathrm{df}=1 ; p=0.007\right)$, demonstrating that significantly more subjects claim that a 'particularly good German' does not exist.

Regarding question (2), 31 (56.4\%) students agree that there are Standard German words which are exclusively used in South Tyrol, while 24 (43.6\%) disagree. A one-sample proportion test showed that the answers of the two groups did not differ significantly $(p>0.42)$. I shall now focus only on those 31 subjects who agree that there are Standard German words which are exclusively used in South Tyrol: 16 (51.6\%) consider these words to be equally correct as the German equivalents from other German-speaking countries, six $(19.4 \%)$ think that they are less correct, and four $(12.9 \%)$ do not know the answer to this question (five students do not provide an answer at all) ${ }^{12}$.

A total of 24 out of 31 students list 14 examples themselves, while seven subjects do not provide any examples at all. As presented in Table 3, the lexical item Targa 'number plate' was named by ten students; followed by the item Kondominium 'multiple-family dwelling', which was mentioned by eight students; and the terms Hydrauliker 'plumber' and Melanzane 'eggplant' were both named by five students. All the other lexical items were listed less than five times. Table 3 also presents whether these items are reported in the recently republished Variantenwörterbuch des Deutschen (Ammon et al. 2016): the table lists the country where it is used ( $\mathrm{A}=$ Austria, $\mathrm{CH}=$ Switzerland, $\mathrm{D}=$ Germany, LUX = Luxembourg, STIR = South Tyrol), and the page number. As can be observed, seven out of 14 items are marked as STIR in the Variantenwörterbuch des Deutschen, two as 'common German' (gemeindt.), while three are not listed at all (Targa 'number plate'13, Ausweis 'identity card' and halt 'just, simply'). Two lexical items, Melanzani 'eggplant' and heuer 'this year', are marked as national variants used in other German-speaking countries, without mentioning South Tyrol.

A six-point scale ('often', 'sometimes', 'rarely', 'never', 'I do not know' and 'n/a') was used to investigate research question (3), asking our subjects whether linguistic variation plays or played any role during their educational path. Although Saxalber-Tetter and Lanthaler (1994) already mentioned its importance more than 25 years ago, it seems that this has not yet been taken up in everyday school life.

As shown in Figure 1, linguistic variation was a "rarely" ( $n=26 ; 47.3 \%)$ or "never" ( $n=13 ; 23.6 \%$ ) discussed topic during high school, even though training material for German lessons exists, such as Saxalber-Tetter (1994), Hofer (2013) and the European Language Portfolio (Das Europäische Sprachenportfolio) ${ }^{14}$, which can be used in primary/secondary school and high school. This, however, changes once our students attend university: the majority claims that it is an "often" $(n=31 ; 56.4 \%)$ or at least a "sometimes" $(n=22 ; 40.0 \%)$ discussed topic. 
Table 3. Words listed in the questionnaire by university students.

\begin{tabular}{ccc}
\hline Lexical Item & Number of Nominations & $\begin{array}{c}\text { Variantenwörterbuch des Deutschen } \\
\text { (Ammon et al. 2016) }\end{array}$ \\
\hline Targa 'number plate' & $n=10$ & - \\
Kondominium 'multiple-family dwelling' & $n=8$ & STIR (p. 406) \\
Hydrauliker 'plumber' & $n=5$ & STIR (p. 343) \\
Melanzane 'eggplant' & $n=5$ & A (Melanzani: p. 470) \\
Peperoni 'pepper' & $n=4$ & CH and STIR (p. 532) \\
Identitätskarte 'identity card' & $n=4$ & CH, LUX and STIR (p. 345) \\
Rucola 'rocket (salad)/arugula' & $n=3$ & (gemeindt. 15 p. 606) \\
heuer 'this year' & $n=2$ & A, CH and D-südost (p. 330) \\
Ausweis 'identity card' & $n=1$ & - \\
halt 'just, simply' & $n=1$ & - \\
Griffelschachtel 'pencil case' & $n=1$ & STIR (p. 294) \\
Sanitätsbetrieb 'health department' & $n=1$ & STIR (p. 616) \\
Oberschule 'high school' & $n=1$ & STIR (p. 507) \\
Sugo 'tomato sauce' & $n=1$ & (gemeindt., p. 726) \\
\hline Total & $\mathrm{N}=47$ & \\
\hline
\end{tabular}

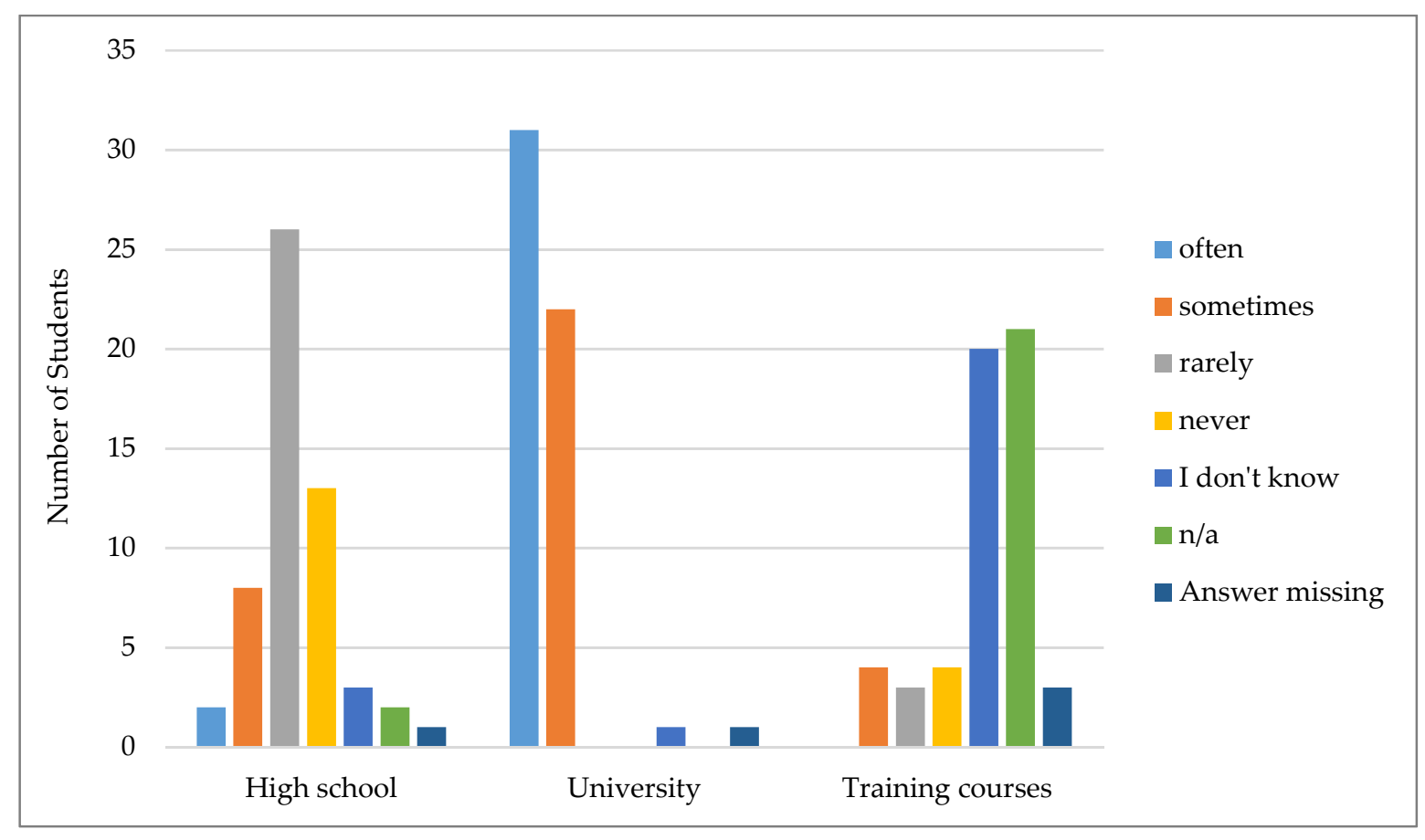

Figure 1. Discussion of linguistic variation during subjects' educational path.

Regarding training courses, i.e., follow-up training for in-service teachers, Figure 1 shows that the majority $(n=41 ; 74.5 \%)$ either did not know the answer to this question or it was not applicable to them. One possible explanation for their responses is that our subjects were still in their first year of the Master in Primary Education and therefore have not attended a training course yet.

Finally, the last question dealt with discussing linguistic variation of the German language with their future pupils at school. Using a four-point scale $(1=$ 'very important', 2 = 'important', 3 = 'less important', 4 = 'not important at all'), Table 4 summarizes absolute numbers, percentage numbers and means scores (and SD) for each attitude-related statement separately from each other. 
Table 4. Students' opinion regarding the discussion of the variation within the German language at school.

\begin{tabular}{|c|c|c|c|c|c|}
\hline $\begin{array}{l}\text { How Important Is the Discussion of the } \\
\text { Following Topics in German Lessons? }\end{array}$ & $\begin{array}{c}1=\text { Very } \\
\text { Important }\end{array}$ & $\begin{array}{c}2= \\
\text { Important }\end{array}$ & $\begin{array}{c}3=\text { Less } \\
\text { Important }\end{array}$ & $\begin{array}{c}4=\text { Not } \\
\text { Important at All }\end{array}$ & $\begin{array}{c}\text { Mean Score } \\
\text { (SD) }\end{array}$ \\
\hline $\begin{array}{l}\text { German non-standard varieties } \\
\text { in general }\end{array}$ & $\begin{array}{c}2 \\
(3.6 \%)\end{array}$ & $\begin{array}{c}12 \\
(21.8 \%)\end{array}$ & $\begin{array}{c}36 \\
(65.5 \%)\end{array}$ & $\begin{array}{c}5 \\
(9.1 \%) \\
\end{array}$ & $\begin{array}{c}2.80 \\
(0.650)\end{array}$ \\
\hline $\begin{array}{c}\text { Linguistic peculiarities of the German } \\
\text { standard variety used in Switzerland, } \\
\text { Austria or Germany }\end{array}$ & $\begin{array}{c}1 \\
(1.8 \%)\end{array}$ & $\begin{array}{c}23 \\
(41.8 \%)\end{array}$ & $\begin{array}{c}28 \\
(50.9 \%)\end{array}$ & $\begin{array}{c}3 \\
(5.5 \%)\end{array}$ & $\begin{array}{c}2.60 \\
(0.627)\end{array}$ \\
\hline $\begin{array}{c}\text { Southern Bavarian variety used in } \\
\text { South Tyrol }\end{array}$ & $\begin{array}{c}19 \\
(34.5 \%)\end{array}$ & $\begin{array}{c}33 \\
(60.0 \%)\end{array}$ & $\begin{array}{c}3 \\
(5.5 \%)\end{array}$ & 0 & $\begin{array}{c}1.71 \\
(0.567)\end{array}$ \\
\hline $\begin{array}{l}\text { Linguistic peculiarities of the German } \\
\text { standard variety used in South Tyrol }\end{array}$ & $\begin{array}{c}23 \\
(41.8 \%)\end{array}$ & $\begin{array}{c}27 \\
(49.1 \%)\end{array}$ & $\begin{array}{c}5 \\
(9.1 \%)\end{array}$ & 0 & $\begin{array}{c}1.67 \\
(0.640)\end{array}$ \\
\hline
\end{tabular}

The vast majority ( $n=41 ; 74.5 \%)$ states that an overall discussion of German nonstandard varieties is not important (at all). Regarding the discussion of linguistic particularities of the German standard variety used in Switzerland, Austria or Germany, slightly more than half of our subjects $(n=31 ; 56.4 \%$ ) state that it is not important (at all), while 24 $(43.6 \%)$ students claim that it is (very) important. As presented in Table 4, the mean scores (and SD) for both statements are high, $2.80(\mathrm{SD}=0.650$, range $1-4)$ and $2.60(\mathrm{SD}=0.627$, range 1-4), respectively.

Nonetheless, the majority thinks that it is (very) important to address the Southern Bavarian variety used in South Tyrol $(n=52 ; 94.5 \%)$ as well as to discuss linguistic particularities of the German standard variety used in South Tyrol $(n=50 ; 90.9 \%)$. Mean scores (and SD) are low for both statements, $1.71(\mathrm{SD}=0.567$, range 1-3) and $1.67(\mathrm{SD}=0.640$, range 1-3), respectively.

\section{Discussion and Conclusions}

German plays a multi-faceted role in the context of South Tyrol. The Southern Bavarian variety constitutes an essential aspect in the life of our Bavarian-speaking subjects as it is the most frequently used code between subjects' and their parents, siblings, partners, children and friends (Table 1). Within a more formal context, as for instance in interaction with university professors as well as with children at preschool and/or primary school, the majority of our subjects claim to use Standard German (Table 2). Due to the fact that the German standard variety is rarely actively spoken in speakers' private life, South Tyroleans sometimes feel insecure when using the language. Nonetheless, South Tyroleans also claim that it is important and necessary to have an adequate language competence in the standard variety (Section 2.1). The educational setting plays an important role as it is not only the place where language competences are developed in the standard variety, but it is also the context in which attitudes can be influenced. As observed for instance by Mioni (1990), Baker (1992) and Sieber and Sitta (1994), teachers should create language-learning situations, where positive experiences with the standard variety can be made in order to build up positive attitudes. The educational context and specifically prospective teachers, therefore, play a crucial role in building up and transmitting positive (or causing negative) attitudes towards the standard variety.

In this paper I examined language attitudes towards German (standard) varieties among South Tyrolean university students and the role of the different German varieties in teacher-training. This paper aimed at answering the following research questions: Which attitudes do university students have towards the different German (standard) varieties? Are they aware of the variation within the German language?

As presented in Section 4, the German standard variety used in Germany still enjoys high prestige: South Tyrolean university students perceive the German used in Germany as 'particularly good', since no other German standard variety, no other country or any other German-speaking realm was listed by those subjects who are convinced about the 
existence of such a 'particularly good German'. These results are in line with Hofer (2020), who found out that the perceived higher status of the German language as spoken in Germany can also be observed among South Tyrolean in-service teachers. However, attitudes concerning the 'correctness' of Standard German words which are exclusively used in South Tyrol demonstrated that 16 of our university students consider them to be equally correct as the German equivalents from other German-speaking countries. Table 3 gives an overview of the lexical items provided by our subjects themselves. As can be seen, 11 out of 14 items are listed in the Variantenwörterbuch des Deutschen (Ammon et al. 2016), in which seven are marked as STIR, two items are labelled to be used in other German-speaking countries, however, without naming South Tyrol (Melanzani 'eggplant' and heuer 'this year'), and two items are classified as 'common German' (Rucola 'rocket (salad)/arugula' and Sugo 'tomato sauce'). Three items (Targa 'number plate', Ausweis 'identity card' and halt 'just, simply') are not listed at all.

We shall now turn to the second important outcome of the present study. Figure 1 demonstrated that the discussion of linguistic variation during subjects' educational path was a "rarely" or even "never" discussed topic during high school. This is rather surprising, as adequate training material for German lessons at primary/secondary schools and high schools is quite available, such as Saxalber-Tetter (1994), and more recently Hofer (2013) and the European Language Portfolio. However, Figure 1 also shows a change in a positive direction: the majority of our subjects' state that linguistic variation is a topic discussed "often" $(56.4 \%)$ or at least "sometimes" $(40.0 \%)$ in university education. Moreover, these prospective teachers also believe that it is important to address the Southern Bavarian variety (94.5\%) and the German standard variety used in South Tyrol (90.9\%) at school (Table 4).

The current results underline the importance of discussing linguistic variation and the concept of the pluricentric variation within the German language in school teaching, in teacher training courses as well as in teaching material (e.g., in curricula, textbooks). This is in line with previous studies conducted in other German-speaking countries, as in the so-called Vollzentren Austria or Switzerland (see Sections 1 and 2.2; de Cillia and Ransmayr 2019). Therefore, the outcome of the current paper may be of interest to other Halbzentren, such as Liechtenstein, Luxembourg or East Belgium, but also to speakers of other pluricentric languages, as for instance English, Spanish or Portuguese. What seems to be more important for so-called Halbzentren is the fact that they lack their own officially recognized language codex. It is therefore not surprising that South Tyrolean teachers as well as teacher-training students consult the Online-Duden or the Duden (Hofer 2017; Leonardi and Hofer 2020). However, as observed by Ammon (1995, p. 406) the numbers of lemmas that are actually marked as Südtirolismen in the Duden and the Österreichisches Wörterbuch are apparently vanishingly small. The absence of the words in the reference books may cause that the standard as used in South Tyrol is not perceived as standard by the speakers themselves. The consequence of these specific standard variants not being perceived as standard is that they are not used by their speakers precisely because they are considered local or dialectal (Ciccolone 2010). So, instead of viewing and perceiving their own standard variety as dialectal, as inferior to the German standard variety used in Germany or to consider it even "to be a potential obstacle for an envisaged career in the dominating nations" (Muhr 2005, p. 15), teachers should make their pupils aware of the linguistic norms and communicative features of their own standard variety (Muhr 2005). In order to be able to do so, teacher-training students must have the opportunity to learn about these concepts and definitions as well as made aware of the (socio)linguistic situation in South Tyrol. As argued by Lasagabaster (2005, p. 403), the role of (language) teachers "is not just to teach the language and impart knowledge, but also to foster positive attitudes towards different languages and varieties". With regard to the educational and pedagogical context in general, it is therefore important to address linguistic diversity as well as to raise and promote awareness in teacher training courses and (foreign) language teaching at schools and universities in order to create sufficient knowledge of practical handling regarding the issue of standard varieties in the German language. In raising 
critical awareness and generating awareness about the equality of national varieties, these prospective teachers will show more acceptance and a more confident use of the German standard variety spoken and written in South Tyrol, which they will ultimately pass on to their pupils. Consequently, their pupils will show greater language awareness themselves and become self-confident speakers and writers in all their varieties.

Funding: This research received no external funding.

Institutional Review Board Statement: The study was approved by the Ethical Research Committee of the Free University of Bozen-Bolzano (AMAT Cod 2020_11, protocol number 8, 21 December 2020).

Informed Consent Statement: Informed consent was obtained from all subjects involved in the study.

Data Availability Statement: The data presented in this study are available on request from the corresponding author. The data are not publicly available due to privacy restrictions.

Acknowledgments: I would like to thank the editor and the anonymous reviewers for their constructive and much valued comments.

Conflicts of Interest: The author declares no conflict of interest.

\section{Appendix A. English Translation of the Questionnaire}

We are investigating the role of the German language in South Tyrolean schools. This questionnaire forms a very important part of our investigation. We therefore thank you very much for your valuable cooperation! If you have any questions, please do not hesitate to contact us. If you are interested in the results of this research, please send us an e-mail.

All information will remain anonymous. By taking part in this study, you agree that your anonymized data will be used for academic purposes only (e.g., papers, presentations).

Thank you very much!

\section{Part (1): Questions}

1. In your opinion, does a 'particularly good German' exist?
$\square$ yes
$\square$ no

If so, where (country, region) is it spoken?

2. Do you think there are Standard German words which are exclusively used in South Tyrol but not in any other German-speaking areas?

$$
\square \text { yes } \quad \square \text { no }
$$

If "yes", can you give examples?

Do you consider them to be:

$\square$ equally correct as their equivalents used in other German-speaking countries,

$\square$ less correct than their equivalents used in other German-speaking countries,

$\square$ I do not know.

3. Was or is linguistic variation a topic of discussion during your education?

High school:

$\square$ often $\square$ sometimes $\square$ rarely $\square$ never $\square$ I do not know $\square$ n/a

University:

$\square$ often $\square$ sometimes $\square$ rarely $\square$ never $\square$ I do not know $\square$ n/a

Training courses:

$\square$ often $\square$ sometimes $\square$ rarely $\square$ never $\square$ I do not know $\square$ n/a

4. In your opinion, how important is the discussion of the variation within the German language at school?

German non-standard varieties in general:

$\square$ very important $\square$ important $\square$ less important $\square$ not important at all

Linguistic peculiarities of the German standard variety used in Switzerland, Austria, or Germany:

$\square$ very important $\square$ important $\square$ less important $\square$ not important at all

Southern Bavarian variety used in South Tyrol:

$\square$ very important $\square$ important $\square$ less important $\square$ not important at all

Linguistic peculiarities of the German standard variety used in South Tyrol:

$\square$ very important $\square$ important $\square$ less important $\square$ not important at all 
5 Which reference books or dictionaries do you use in case of linguistic insecurities (e.g., grammar, orthography)? (Multiple answers possible)
$\square$ Duden Universalwörterbuch
$\square$ Dudengrammatik
$\square$ Online-Duden
$\square$ Wahrig (Brockhaus)
$\square$ Österreichisches Wörterbuch (ÖWB)
$\square$ Variantenwörterbuch
$\square$ Other dictionary:
$\square$ Bilingual dictionary:
$\square$ nowhere

[Results to this question can be found in Leonardi and Hofer (2020, pp. 157-58).]

Part (2): Student essay

Please read the following essay written by an 11-year-old student. Are there any expressions or phrases that you would correct?

[The original German essay can be found in Hofer (2020, p. 243)].

Part (3): Personal information

$\square$ male $\square$ female

Age:

Place of birth:

If you were not born in South Tyrol, since when do you live here? I have lived here for years.

Place of residence:

What is your native language/What are your native languages?

Which variety/varieties do you use with the following people? (Multiple answers possible)

Mother:

$\square$ Southern Bavarian variety $\square$ Standard German $\quad \square$ Umgangssprachliches Deutsch $\square$ Ladin

$\square$ Italian variety $\square$ Standard Italian $\square$ other variety

Father:

$\square$ Southern Bavarian variety $\square$ Standard German $\quad \square$ Umgangssprachliches Deutsch $\square$ Ladin

$\square$ Italian variety $\square$ Standard Italian $\square$ other variety Sibling/s:

$\square$ Southern Bavarian variety $\square$ Standard German $\square$ Umgangssprachliches Deutsch $\square$ Ladin

$\square$ Italian variety $\square$ Standard Italian $\square$ other variety

Partner:

$\square$ Southern Bavarian variety $\square$ Standard German $\quad \square$ Umgangssprachliches Deutsch $\square$ Ladin

$\square$ Italian variety $\square$ Standard Italian $\square$ other variety

Children:

$\square$ Southern Bavarian variety $\square$ Standard German $\quad \square$ Umgangssprachliches Deutsch $\square$ Ladin

$\square$ Italian variety $\square$ Standard Italian $\square$ other variety

Friends:

$\square$ Southern Bavarian variety $\square$ Standard German $\quad \square$ Umgangssprachliches Deutsch $\square$ Ladin

$\square$ Italian variety $\square$ Standard Italian $\square$ other variety

Children at Preschool/Primary School:

$\square$ Southern Bavarian variety $\square$ Standard German $\square$ Umgangssprachliches Deutsch $\square$ Ladin

$\square$ Italian variety $\square$ Standard Italian $\square$ other variety

University Professors:

$\square$ Southern Bavarian variety $\square$ Standard German $\quad \square$ Umgangssprachliches Deutsch $\square$ Ladin

$\square$ Italian variety $\square$ Standard Italian $\square$ other variety

$\square \mathrm{n} / \mathrm{a}$ 


\title{
Appendix B. Original German Language Questionnaire
}

\begin{abstract}
Liebe Studierende!
Wir untersuchen die Rolle der deutschen Sprache an Südtiroler Schulen. Dieser Fragebogen bildet einen sehr wichtigen Teil unserer Untersuchung. Wir danken Ihnen deshalb ganz herzlich für Ihre wertvolle Mitarbeit! Bei Rückfragen können Sie uns gerne kontaktieren. Wenn Sie Interesse an den Ergebnissen dieser Forschung haben, schicken Sie uns bitte ganz einfach eine E-Mail.
\end{abstract}

Alle Ihre Angaben bleiben selbstverständlich anonym und werden nur von uns und in anonymer Form eingesehen. Mit der Teilnahme an dieser Studie erklären Sie sich damit einverstanden, dass Ihre anonymisierten Daten ausschließlich für wissenschaftliche Zwecke (z.B. Publikationen, Präsentationen) verwendet werden.

Nochmals vielen herzlichen Dank!

Teil (1): Fragen

1. Gibt es Ihrer Meinung nach ein besonders gutes Deutsch?

$\square$ ja $\square$ nein

Wenn ja, wo (in welchem Land/in welcher Region) wird es gesprochen?

2. Gibt es Ihrer Meinung nach standarddeutsche/hochdeutsche Wörter, die nur in Südtirol gebraucht werden, nicht aber in anderen deutschsprachigen Gebieten?

$\square$ ja $\square$ nein

Wenn ja, können Sie Beispiele nennen?

Finden Sie diese Wörter:

$\square$ genauso korrekt wie ihre Entsprechungen,

$\square$ weniger korrekt als ihre Entsprechungen,

$\square$ weiß nicht.

3. Wurde bzw. wird sprachliche Variation (z.B. Varietäten der deutschen Standardsprache, Dialekte des Deutschen) während Ihrer Ausbildung thematisiert? an der Oberschule:

$\square$ häufig $\square$ manchmal $\square$ selten $\square$ nie $\square$ weiß nicht $\square$ nicht zutreffend

an der Universität:

$\square$ häufig $\square$ manchmal $\square$ selten $\square$ nie $\square$ weiß nicht $\square$ nicht zutreffend

bei Fortbildungen:

$\square$ häufig $\square$ manchmal $\square$ selten $\square$ nie $\square$ weiß nicht $\square$ nicht zutreffend

4. Wie wichtig sind Ihrer Meinung nach die folgenden Themen im Deutschunterricht in Südtirol? Deutsche Dialekte:

$\square$ sehr wichtig $\square$ wichtig $\square$ wenig wichtig $\square$ überhaupt nicht wichtig

Besonderheiten des Standarddeutschen/Hochdeutschen in Österreich, der Schweiz und Deutschland:

$\square$ sehrwichtig $\square$ wichtig $\square$ wenig wichtig $\square$ überhaupt nicht wichtig

Dialekte in Südtirol:

$\square$ sehr wichtig $\quad \square$ wichtig $\square$ wenig wichtig $\square$ überhaupt nicht wichtig

Besonderheiten des Standarddeutschen/Hochdeutschen in Südtirol:

$\square$ sehr wichtig $\quad \square$ wichtig $\square$ wenig wichtig $\square$ überhaupt nicht wichtig

5. Wenn Sie selbst einen sprachlichen Zweifel haben (z.B. Grammatik, Orthographie o. Ä.), wo sehen Sie nach? (Mehrfachnennungen möglich)

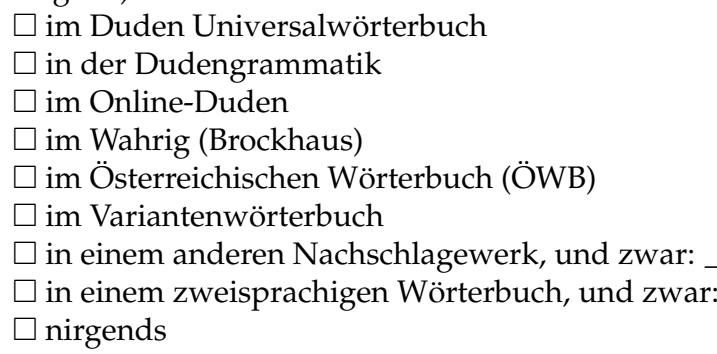

[Results to this question can be found in Leonardi and Hofer (2020, pp. 157-58).]

Teil (2): Aufsatz

Bitte lesen Sie den folgenden Aufsatz eines 11-jährigen Schülers durch. Gibt es Ausdrücke bzw. Formulierungen, die Sie in Hinblick auf normative Sprachrichtigkeit und Ausdruck korrigieren würden.

[The original German essay can be found in Hofer (2020, p. 243)]. 


\section{Teil (3): Angaben zur Person}

$\square$ männlich $\square$ weiblich

Alter:

Geburtsort:

Wenn Sie nicht in Südtirol geboren sind, wie lange leben Sie dann schon hier? Seit Jahren.

Wohnort:

Welche Sprache(n) oder welche/n Dialekt(e) würden Sie als Ihre Muttersprache(n) bezeichnen?

Wie sprechen Sie mit den folgenden Personen? (Mehrfachnennungen möglich) mit meiner Mutter:

$\square$ einen Südtiroler Dialekt $\square$ Standarddeutsch/Hochdeutsch $\square$ Umgangssprachliches Deutsch $\square$ Ladinisch $\quad \square$ einen italienischen Dialekt $\square$ Standarditalienisch

$\square$ eine andere Sprache/Varietät, und zwar: $\square$ nicht zutreffend

mit meinem Vater:

$\square$ einen Südtiroler Dialekt $\square$ Standarddeutsch/Hochdeutsch $\square$ Umgangssprachliches Deutsch $\square$ Ladinisch $\square$ einen italienischen Dialekt $\square$ Standarditalienisch

$\square$ eine andere Sprache/Varietät, und zwar: $\square$ nicht zutreffend mit meinen Geschwister:

$\square$ einen Südtiroler Dialekt $\square$ Standarddeutsch/Hochdeutsch $\square$ Umgangssprachliches Deutsch $\square$ Ladinisch $\square$ einen italienischen Dialekt $\square$ Standarditalienisch

$\square$ eine andere Sprache/Varietät, und zwar: $\square$ nicht zutreffend

mit meinem Partner bzw. meiner Partnerin:

$\square$ einen Südtiroler Dialekt $\square$ Standarddeutsch/Hochdeutsch $\square$ Umgangssprachliches Deutsch $\square$ Ladinisch $\square$ einen italienischen Dialekt $\square$ Standarditalienisch

$\square$ eine andere Sprache/Varietät, und zwar: $\square$ nicht zutreffend

mit meinen Kindern:

$\square$ einen Südtiroler Dialekt $\square$ Standarddeutsch/Hochdeutsch $\square$ Umgangssprachliches Deutsch $\square$ Ladinisch $\square$ einen italienischen Dialekt $\square$ Standarditalienisch

$\square$ eine andere Sprache/Varietät, und zwar: $\square$ nicht zutreffend mit meinen Freunden:

$\square$ einen Südtiroler Dialekt $\square$ Standarddeutsch/Hochdeutsch $\square$ Umgangssprachliches Deutsch $\square$ Ladinisch $\quad \square$ einen italienischen Dialekt $\square$ Standarditalienisch

$\square$ eine andere Sprache/Varietät, und zwar: $\square$ nicht zutreffend

mit meinen SchülerInnen/Kindern während des Unterrichts/im Kindergarten (z.B. bei Praktika):

$\square$ einen Südtiroler Dialekt $\square$ Standarddeutsch/Hochdeutsch $\square$ Umgangssprachliches Deutsch $\square$ Ladinisch $\square$ einen italienischen Dialekt $\square$ Standarditalienisch

$\square$ eine andere Sprache/Varietät, und zwar:

$\square$ nicht zutreffend

mit meinen Universitätsprofessoren:

$\square$ einen Südtiroler Dialekt $\square$ Standarddeutsch/Hochdeutsch $\square$ Umgangssprachliches Deutsch $\square$ Ladinisch $\quad \square$ einen italienischen Dialekt $\square$ Standarditalienisch

$\square$ eine andere Sprache/Varietät, und zwar:

$\square$ nicht zutreffend

\section{Notes}

1 In this paper, the Southern Bavarian variety only refers to the dialectal variety used in South Tyrol.

2 A more detailed description of the (German) varieties used in South Tyrol can be found in Riehl (2000), Abfalterer (2007), Ciccolone (2010) and Glück et al. (2019, pp. 254-61).

3 In order to determine the preference for national variants, a common method is to examine subjects' correction patterns in using a fictitious student essay, as for instance in Ammon (1995), Gatta (2017), de Cillia and Ransmayr (2019), and Hofer (2020), or sample sentences as in Fink (2016). Scharloth (2005a) and Scharloth (2005b) conducted a subjective evaluation test and a questionnaire survey on language attitudes in Switzerland.

4 National variants in Germany are called Deutschlandisms or Teutonisms, in Austria Austriacisms and in Switzerland Helvetisms (Ammon 1995; Ammon et al. 2004, 2016). Primary South Tyrolisms (Primäre Südtirolismen) are lexical items which are exclusively used in South Tyrol, while secondary South Tyrolisms (Sekundäre Südtirolismen) are also used in other centres, such as Austria or Switzerland (Abfalterer 2007).

5 For different reasons (see Muhr 2005), however, not all variety-specific features might find their way into dictionaries or reference books.

6 An approval form from the ethics committee was not possible to obtain before undertaking the research because an Ethical Research Committee has only existed since spring 2020 at the Free University of Bozen-Bolzano. However, in a retrospect the Ethical Research Committee of the Free University of Bozen-Bolzano considers the current empirical research as ethically undoubtful (AMAT Cod 2020_11, protocol number 8, 21 December 2020). Data was collected by the author herself and even 
though data collection was completely anonymous, she cannot exclude socially desirable answers. Informed written consent was obtained from all subjects involved in the study in order to analyse and use subjects' data for academic purposes.

7 The university has three Campuses: in Bozen/Bolzano, Brixen/Bressanone and Bruneck/Brunico.

8 In order to be able to compare teachers' and teacher-training students' correction behaviour, the fictitious student essay was adopted from Hofer (2020, p. 243). Teachers and university students were asked to correct an essay that contained no actual 'mistakes', but a series of regionally marked variants of the German standard variety. Results of the comparison between teachers and university students can be found in Leonardi and Hofer (2020).

9 Part (1) of the questionnaire consisted of five questions (see Appendix A). The answers to the question "Which reference books or dictionaries do you use in case of linguistic insecurities?" revealed that almost $93 \%$ of the university students claimed to use the Online-Duden (Leonardi and Hofer 2020, pp. 157-58).

10 The German terms Südtiroler Dialekt (Southern Bavarian variety), Standarddeutsch/Hochdeutsch (Standard German), italienischer Dialekt (Italian variety), Standarditalienisch (Standard Italian) and umgangssprachliches Deutsch (colloquial German) were used in the German language questionnaire (see Appendix B).

11 A definition can be found in Glück et al. (2019, pp. 257-58).

12 As correctly noted by an anonymous reviewer, several students either answered "I do not know" or left answers blank. As the reasons for the missing answers are only speculative (e.g., lack of knowledge or no interest in the questionnaire survey), unfortunately no satisfactory answer can be given to this phenomenon. Furthermore, the anonymous reviewer noted that the questionnaire does not provide an option if students consider lexical items to be more correct than the German equivalents used in other German-speaking countries. Of course, this may not only skew the results and lead the data in a certain direction, but could also be responsible for the blank responses.

13 Targa 'number plate' is Italian and it is commonly used in the Southern Bavarian variety, while the German equivalents Kennzeichenschild or Nummerntafel are rarely used.

14 Available online: https://www.provinz.bz.it/bildung-sprache/didaktik-beratung/sprachenportfolio-esp.asp\#accept-cookies (accessed on 13 July 2021).

15 gemeindt. = common German.

\section{References}

Abel, Andrea, and Stefanie Anstein. 2011. Korpus Südtirol-Varietätenlinguistische Untersuchungen. In Korpora in Lehre und Forschung. Edited by Andrea Abel and Renata Zanin. Bozen and Bolzano: Bozen-Bolzano University Press, pp. 29-54. Available online: http:/ / pro.unibz.it/library/bupress/publications/fulltext/9788860460950.pdf (accessed on 13 July 2021).

Abel, Andrea. 2007. Werkstattbericht über das Projekt “Die Südtiroler SchülerInnen und die Zweitsprache: Eine linguistische und sozialpsychologische Untersuchung". Linguistik Online 32: 3-14. Available online: https://bop.unibe.ch/linguistik-online/ article/view/533 (accessed on 13 July 2021). [CrossRef]

Abfalterer, Heidemaria. 2007. Der Südtiroler Sonderwortschatz aus Plurizentrischer Sicht: Lexikalisch-Semantische Besonderheiten im Standarddeutsch Sïdtirols. Innsbruck: Innsbruck University Press.

Ajzen, Icek. 2005. Attitudes, Personality and Behaviour, 2nd ed. Maidenhead/Berkshire: Open University Press. Available online: https:/ / psicoexperimental.files.wordpress.com/2011/03/ajzeni-2005-attitudes-personality-and-behaviour-2nd-ed-openuniversity-press.pdf (accessed on 13 July 2021).

Ammon, Ulrich, Hans Bickel, Jakob Ebner, Ruth Esterhammer, Markus Gasser, Lorenz Hofer, Birte Kellermeier-Rehbein, Heinrich Löffler, Doris Mangott, Hans Moser, and et al. 2004. Variantenwörterbuch des Deutschen. Die Standardsprache in Österreich, der Schweiz und Deutschland sowie in Liechtenstein, Luxemburg, Ostbelgien und Südtirol. Berlin and New York: De Gruyter.

Ammon, Ulrich, Hans Bickel, and Alexandra Nicole Lenz. 2016. Variantenwörterbuch des Deutschen. Die Standardsprache in Österreich, der Schweiz, Deutschland, Liechtenstein, Luxemburg, Ostbelgien und Südtirol sowie Rumänien, Namibia und Mennonitensiedlungen, 2nd ed. Berlin and Boston: De Gruyter.

Ammon, Ulrich. 1995. Die deutsche Sprache in Deutschland, Österreich und der Schweiz: Das Problem der nationalen Varietäten. Berlin and New York: De Gruyter.

Ammon, Ulrich. 2015. On the social forces that determine what is standard in a language-with a look at the norms of non-standard language varieties. Bulletin VALS-ASLA 3: 53-67.

Anstein, Stefanie, Margit Oberhammer, and Stefanos Petrakis. 2011. Korpus Südtirol—Aufbau und Abfrage. In Korpora in Lehre und Forschung. Edited by Andrea Abel and Renata Zanin. Bozen and Bolzano: Bozen-Bolzano University Press, pp. 15-28. Available online: http:/ / pro.unibz.it/library/bupress/publications/fulltext/9788860460950.pdf (accessed on 13 July 2021).

ASTAT. 2015. Provincial Statistics Institute. In Südtiroler Sprachbarometer. Sprachgebrauch und Sprachidentität in Südtirol-2014. Bozen and Bolzano: Autonomous Province of South Tyrol. Available online: https://astat.provinz.bz.it/de/aktuelles-publikationeninfo.asp?news_action=4\&news_article_id=516194 (accessed on 13 July 2021).

ASTAT. 2020. Provincial Statistics Institute. In South Tyrol in Figures 2020. Bozen and Bolzano: Autonomous Province of South Tyrol. Available online: https:/ / astat.provinz.bz.it/downloads/Siz_2020-eng.pdf (accessed on 13 July 2021).

Baker, Colin. 1992. Attitudes and Language. Clevedon: Multilingual Matters. 
Ciccolone, Simone. 2010. Lo standard tedesco in Alto Adige: L'orientamento alla norma dei tedescofoni sudtirolesi. Milano: LED Edizioni Universitarie. Clyne, Michael. 1992a. Pluricentric Languages-Introduction. In Pluricentric Languages. Differing in Norms in Different Nations. Edited by Michael Clyne. Berlin and New York: De Gruyter, pp. 1-9.

Clyne, Michael. 1992b. German as a pluricentric language. In Pluricentric languages. Differing Norms in Different Nations. Edited by Michael Clyne. Berlin and New York: De Gruyter, pp. 117-47.

Clyne, Michael. 2004. Pluricentric Language/Plurizentrische Sprache. In Sociolinguistics/Soziolinguistik. An International Handbook of the Science of Language and Society/Ein internationales Handbuch zur Wissenschaft von Sprache und Gesellschaft, 2nd ed. Edited by Ulrich Ammon, Norbert Dittmar, Klaus J. Mattheier and Peter Trudgill. Berlin and New York: De Gruyter, vol. 1, pp. 296-300.

de Cillia, Rudolf, and Jutta Ransmayr. 2019. Österreichisches Deutsch macht Schule. Bildung und Deutschunterricht im Spannungsfeld von Sprachlicher Variation und Norm. Wien: Böhlau Verlag.

Dollinger, Stefan. 2019. The Pluricentricity Debate. On Austrian German and other Germanic Standard Varieties. New York: Routledge.

Fink, Ilona Elisabeth. 2014. Wimmerl is eigentlich wirklich a Mundortwort, oba, Pickel' is a net schöner. Ergebnisse einer Studie über das Korrekturverhalten von österreichischen Lehrenden. In ide. Informationen zur Deutschdidaktik. Zeitschrift für den Deutschunterricht in Wissenschaft und Schule. Österreichisches Deutsch und Plurizentrik. Edited by Jutta Ransmayr, Andrea Moser-Pacher and Ilona Elisabeth Fink. Innsbruck: Studienverlag, pp. 78-87.

Fink, Ilona Elisabeth. 2016. Language loyalty to Austrian German: Conclusions of a research project at Austrian schools. In Pluricentric Languages and Non-Dominant Varieties Worldwide. Part 1: Pluricentric Languages across Continents. Features and Usage. Series: Österreichisches Deutsch—Sprache der Gegenwart. Edited by Rudolf Muhr. Frankfurt a. M.: Peter Lang, pp. 267-80.

Fishbein, Martin, and Icek Ajzen. 1975. Belief, Attitude, Intention and Behavior: An Introduction to Theory and Research. Reading: Addison-Wesley. Gardner, Robert C., and Wallace E. Lambert. 1972. Attitudes and Motivation: Second Language Learning. Rowley: Newbury House.

Gatta, Adriana. 2017. Untersuchung des Korrekturverhaltens von Lehrpersonen auf der Sekundarstufe II in Bezug auf nationale Varianten der Schweizer Standardsprache. In Standardsprache Zwischen Norm und Praxis. Theoretische Betrachtungen, Empirische Studien und Sprachdidaktische Ausblicke. Edited by Winifred V. Davies, Annelies Häcki Buhofer, Regula Schmidlin, Melanie Wagner and Eva Lia Wyss. Tübingen: Narr Francke Attempto, pp. 359-92.

Glück, Alexander, Mara Maya Victoria Leonardi, and Claudia Maria Riehl. 2019. Südtirol. In Handbuch des Deutschen in West- und Mitteleuropa: Sprachminderheiten und Mehrsprachigkeitskonstellationen. Edited by Rahel Beyer and Albert Plewnia. Tübingen: Narr, pp. 245-280.

Hofer, Silvia. 2013. Deutsch ist Nicht Gleich Deutsch—Paese che vai, Tedesco Che Trovi. Materialien Für Den Deutschunterricht in Südtirol. Bozen and Bolzano: Europäische Akademie Bozen.

Hofer, Silvia. 2017. Das Korrekturverhalten von Südtiroler Deutschlehrpersonen und ihre Rolle als Normautoritäten im sozialen Kräftefeld der deutschen Standardsprache in Südtirol. In ÖDaF-Mitteilungen: "Man lernt nicht mit dem Kopf allein". Zur Rolle von Emotionen im DaF/DaZ-Unterricht. Edited by Österreichischer Verband für Deutsch als Fremdsprache/Zweitsprache. Göttingen: V\&R unipress, pp. 79-95.

Hofer, Silvia. 2020. Deutsch Ist Nicht Gleich Deutsch: Zum Umgang mit der Plurizentrischen Sprache Deutsch und Standardsprachlicher Variation an Südtiroler Oberschulen. Ph.D. dissertation, Universität Wien, Wien, Austria.

Lanthaler, Franz. 1990. Dialekt und Zweisprachigkeit in Südtirol. In Mehr als eine Sprache. Zu einer Sprachstrategie in Südtirol. Edited by Alberto M. Mioni, Kurt Egger and Franz Lanthaler. Meran and Merano: Alpha \& Beta Verlag, pp. 57-81.

Lasagabaster, David. 2005. Attitude/Einstellung. In Sociolinguistics/Soziolinguistik. An International Handbook of the Science of Language and Society/Ein Internationales Handbuch zur Wissenschaft von Sprache und Gesellschaft, 2nd ed. Edited by Ulrich Ammon, Norbert Dittmar, Klaus J. Mattheier and Peter Trudgill. Berlin and New York: De Gruyter, vol. 1, pp. 399-405.

Leonardi, Mara Maya Victoria. 2020. "I hardly ever practice the real Standard German." Self-reported language use and language proficiency in South Tyrol (Italy). Linguistik Online 102: 83-98. Available online: https://bop.unibe.ch/linguistik-online/article/ view / 6825 (accessed on 1 August 2021). [CrossRef]

Leonardi, Mara Maya Victoria. Forthcoming. Varietätengebrauch und Spracheinstellungen. Eine quantitative Untersuchung sprachbiographischer Interviews mit MaturantInnen an deutschsprachigen Oberschulen in Südtirol. In Tagungsband zur 14. BayerischÖsterreichischen Dialektologentagung. Edited by Stephan Elspaß, Philip Vergeiner and Dominik Wallner.

Leonardi, Mara Maya Victoria, and Silvia Hofer. 2020. Standard language variation in German at educational institutions in South Tyrol (Italy). In Pluricentric Languages Worldwide. Series 1: Pluricentric Theory. Pluricentric Theory beyond Dominance and Non-Dominance: A Critical View. Edited by Rudolf Muhr and Juan Thomas. Graz and Berlin: pcl-PRESS, pp. 151-166.

Mioni, Alberto M. 1990. Bilinguismo intra- e intercomunitario in Alto Adige/Südtirol: Considerazioni sociolinguistiche. In Mehr als eine Sprache. Zu einer Sprachstrategie in Südtirol. Edited by Alberto M. Mioni, Kurt Egger and Franz Lanthaler. Meran and Merano: Alpha \& Beta Verlag, pp. 13-35.

Muhr, Rudolf. 1995. Zur Sprachsituation in Österreich und zum Begriff ,Standardsprache' in plurizentrischen Sprachen. Sprache und Identität in Österreich. In Österreichisches Deutsch. Linguistische, Sozialpsychologische und Sprachpolitische Aspekte einer Nationalen Variante des Deutschen. (=Materialien und Handbücher zum österreichischen Deutsch und zu Deutsch als Fremdsprache. Bd. 2). Edited by Rudolf Muhr, Richard Schrodt and Peter Wiesinger. Wien: Hölder-Pichler-Tempsky, pp. 75-109.

Muhr, Rudolf. 2005. Language attitudes and language conceptions in non-dominating varieties of pluricentric languages. In Standardvariationen und Sprachideologien in Verschiedenen Sprachkulturen der Welt/Standard Variations and Language Ideologies in Different Language Cultures around the World. Edited by Rudolf Muhr. Frankfurt am Main: Peter Lang, pp. 11-20. 
Riehl, Claudia Maria. 1994. Das Problem von 'Standard' und 'Norm' am Beispiel der deutschsprachigen Minderheit in Südtirol. In Mehrsprachigkeit in Europa-Hindernis oder Chance? Edited by Uta Helfrich and Claudia Maria Riehl. Wilhelmsfeld: Egert, pp. 149-64.

Riehl, Claudia Maria. 2000. Deutsch in Südtirol. In Minderheiten- und Regionalsprachen in Europa. Edited by Jan Wirrer. Opladen: Westdeutscher Verlag, pp. 235-46.

Riehl, Claudia Maria. 2001. Schreiben, Text und Mehrsprachigkeit. Zur Textproduktion in Mehrsprachigen Gesellschaften am Beispiel der Deutschsprachigen Minderheiten in Südtirol und Ostbelgien. Tübingen: Stauffenburg.

Riehl, Claudia Maria. 2007. Varietätengebrauch und Varietätenkontakt in Südtirol und Ostbelgien. Linguistik Online 32: 105-17. Available online: https:/ / bop.unibe.ch/linguistik-online/article/view/540 (accessed on 13 July 2021).

Saxalber-Tetter, Annemarie, and Franz Lanthaler. 1994. Deutschunterricht in Südtirol—Sprachdidaktik für den kleinen Raum. In Vielerlei Deutsch. Umgang mit Sprachvarietäten in der Schule. Edited by Peter Klotz and Peter Sieber. Stuttgart: Klett, pp. 78-93.

Saxalber-Tetter, Annemarie. 1982. Einschätzung des Dialekts bei Eltern und Lehrern. Ergebnisse einer Umfrage. In Dialekt und Hochsprache in der Schule. Beiträge zum Deutschunterricht in Südtirol. Beiträge und Vorträge der Tagung über Dialekt und Hochsprache in der Schule, Brixen 1981. Edited by Kurt Egger. Bozen and Bolzano: Südtiroler Kulturinstitut, pp. 42-74.

Saxalber-Tetter, Annemarie. 1994. Dialekt-Hochsprache als Unterrichtsthema: Anregungen für die Deutschlehrer/innen der Mittel- und Oberschule, 2nd ed. Bozen and Bolzano: Südtiroler Kulturinstitut.

Scharloth, Joachim. 2005a. Zwischen Fremdsprache und nationaler Varietät. Untersuchungen zum Plurizentrizitätsbewusstsein der Deutschschweizer. In Standardvariation und Sprachideologien in Verschiedenen Sprachkulturen der Welt. Edited by Rudolf Muhr. Frankfurt am Main: Peter Lang, pp. 21-44.

Scharloth, Joachim. 2005b. Asymmetrische Plurizentrizität und Sprachbewusstsein. Einstellungen der Deutschschweizer zum Standarddeutschen. Zeitschrift für Germanistische Linguistik 33: 236-67.

Schmidlin, Regula. 2011. Die Vielfalt des Deutschen: S tandard und Variation. Gebrauch, Einschätzung und Kodifizierung einer Plurizentrischen Sprache. Berlin and New York: De Gruyter.

Sieber, Peter, and Horst Sitta. 1994. Zur Rolle der Schule beim Aufbau von Einstellungen zu Dialekt und Standardsprache. In Spracherwerb im Spannungsfeld von Dialekt und Hochsprache. (=Zürcher Germanistische Studien 38). Edited by Harald Burger and Annelies Häcki Buhofer. Frankfurt am Main: Peter Lang, pp. 199-213.

Soares da Silva, Augusto. 2014. Pluricentricity: Language Variation and Sociocognitive Dimensions. Edited by Augusto Soares da Silva. Berlin and Boston: De Gruyter.

Wandruszka, Mario. 1979. Die Mehrsprachigkeit des Menschen. München: Piper. 